\title{
Demand Change for International Trade Talents under the Upgrade Process in Beijing
}

\author{
Z.Y. XIE \\ North China University of Technology, Beijing, China
}

\begin{abstract}
In recent years, the development of the environment and e-commerce has brought on profound reform for international trade activities. Colleges' foreign trade profession should adapt these changes, and predict the demand of talents so as to improve the current education mode. The article surveyed the employment market based on 99 foreign trade enterprises' sample in Beijing by questionnaires and interview of managers. The result showed that the trade environment in Beijing has been deteriorating, enterprises have been upgrading their product, but little influence on the talents demand, the prominent problem of fresh graduates is their poor professional foundation, and the critical trouble of the college education is their away from the practice. The article put forward some thoughts on how to change current education ideology and cooperate with enterprises tightly.
\end{abstract}

KEYWORD: Demand for foreign trade talents; College-enterprise cooperation; Talent training

\section{INTRODUCTION}

In recent years, the grim employment situation of the college student has become a focus of society(Chunzi Gong and Liming Zhao,2014). It is attributed to the higher education's lag behind the social demand.

International Economics and Trade is a traditional profession. At present, there are more than 800 domestic universities setting up the profession, and Beijing plays a vital role in cultivating international businessman. According to the statistics released by Beijing Association of Import and Export enterprises, there are about 400 foreign trade enterprises in Beijing. It shows a huge potential demand for foreign trade qualified personnel. However, college graduates still have difficulty in finding jobs. There exists a bit gap between the college graduate and the enterprise's need. Especially, in recent years, Beijing has accelerated the upgrading of the industrial structure, which certainly causes the new changes of the demand for foreign trade talents, and that understanding these changes is vital to reform our professional teaching.

Now, the layout of the capital economic circle is becoming clear, integration of Beijing-Tianjin-Hebei regions development has been risen to national planning level. Beijing has strengthened its high-end leading role on development of the industry, focused on innovation, moved out the low value-added manufacturing or commercial logistic, and relied on elements such as science and technology, ideas, capital, talents to support the development of economic. Another important change is that the popularity of the internet is profoundly changing the traditional international business activities. Large ecommerce platform with the aid of information and the advantage of cost, involved in international trade activities, has changed the traditional trade practice, and has made the process more and more simplified. Third-party payment also challenges the traditional method of payment dominated by banks such as L/C. Retail trade, online payment and international express logistics have become a new trend of international trade in recent years. In order to adapt to the trend and serve the development of capital economy better, our education of international trade profession needs reformation to keep pace with the times.

\section{DESCRIPTION OF THE INVESTIGATION}

\subsection{Purpose of the investigation}

Know about the new changes of the international trade industry in Beijing, the changes of the enterprise's talent demand, and their evaluations on the effect of recruiting college graduates.

\subsection{Respondent of the investigation}

About 99 foreign trade companies in Beijing; 13 
alumni of the grade 2000 engaged in the international trade work who once studied in North China University of Technology.

\section{3 sample source}

We carried out the investigation by making use of the opportunity of the undergraduates' summer internship, entrusting the students who intern in Beijing to complete the questionnaire. The questionnaire was asked to be filled out by the foreign trade department manager or the principal above this level, including their contact way. There should be 99 valid questionnaires finally. The other part is alumni samples, we interviewed 13 alumni who are engaged in foreign trade work at the grade 2000's alumni association this summer, and asked for their opinions on the foreign trade industry, talents demand and school teaching.

\subsection{Contents of the investigation}

What has happened to the environment of foreign trade in Beijing? How do the enterprises adjust their strategies and make a transition? What kind of new methods does it appear in the area of foreign trade? The changes of the talent demand scale and the structure of foreign trade. The current situation of the enterprise's recruiting college graduates, enterprise's evaluation on college students and the college education, enterprise's attitude towards the school-enterprise cooperation.

\subsection{Methods of the investigation}

Combine the questionnaire and interview. At first, conduct the questionnaire survey. Then interview the alumni for some vital problems on the basis of the questionnaire.

\section{ANALYSIS OF THE RESULT}

Questionnaire survey is very important in the investigation. The design of the questionnaire sticks to the goal and is very succinct. There are 15 topics in total in order to make it easy for respondents to complete the questionnaires in 10 minutes. The questionnaire questioned 3 problems, including the foreign trade environment in Beijing and the enterprise's response, the changes of the enterprise's talent demand, the evaluations on the university personnel training.

\subsection{Environment of foreign trade in Beijing and enterprise's countermeasures}

Overall, the environment is deteriorating. As we can see from the figure 1 , although there are some individual differences between the sample enterprises, the share of A and B is up to $55 \%$, D and $\mathrm{E}$ account for $37 \%$. There is a cross-validation between the results and the latest statistics of foreign trade in Beijing. According to the statistics of import and export figures from January to august released by Economic Commission of Beijing, the amount of foreign trade decreases by $4.1 \%$ compared with last year, and the amount in August decreases by $12.4 \%$, including the export monthly decline of $13 \%$.

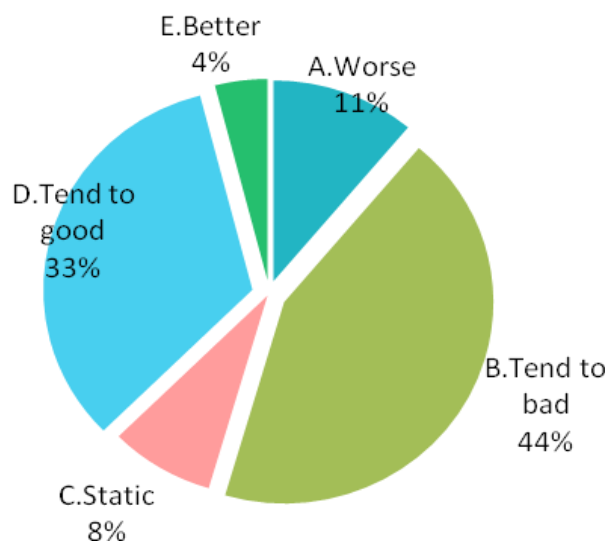

Figure 1. Impact of Economy Situation on Companies' International Business

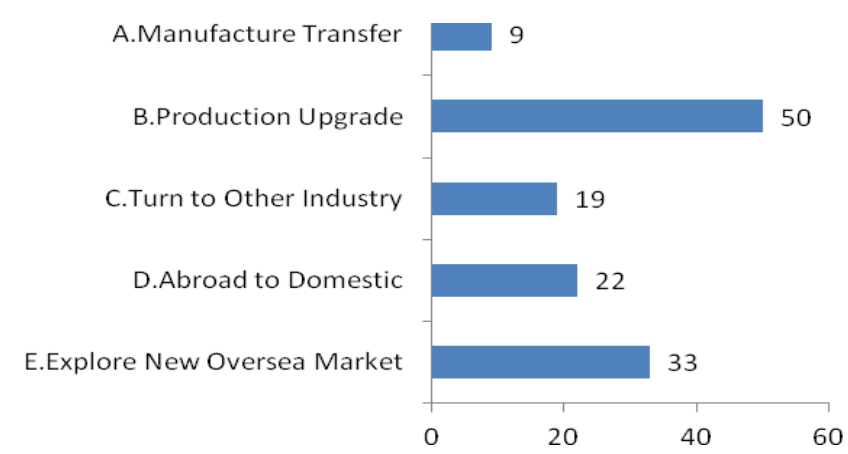

Figure 2. Strategic Choices for Enterprises

Facing with the changes, enterprises were able to take active countermeasures (Figure 2). Fortunately, there are 50 companies upgrading the products, which accounts for 50.5 percent. It shows that foreign trade enterprises have been improving the quality of products. The second strategy is to open up new markets abroad (about a third of the sample). There are also other strategies, including domestic exports, to transform into other industries, or to move production to other factories. We can discover that though the operating cost in Beijing is rising constantly, most foreign trade enterprises are still reluctant to leave, which indicates that theory is inconsistent with the fact. Thus we suggest that government should pay attention to this point when releasing the policy. 


\subsection{Changes in the foreign trade enterprise's talent demand}

In recent years, the operation level of the international trade business has taken place great changes. Among them, the most important change is the e-commerce of foreign trade. In particular, the electronic commerce is changing the traditional mode of foreign trade, which has made more and more process work online. Another change is the specialization of the division and the operation simplification. Electronic foreign trade management system is taking place of paper documents step by step. All those changes have greatly improved the efficiency of the business and lowered the threshold. Sample enterprises generally believe that the most valuable ability is to develop the international market, the key of the international trade talents training has turned into improving marketing skills.

Although the foreign trade environment isn't well, the enterprise's talent demand relatively remains unchanged. Among the 99 companies, there are 14 companies remaining unchanged, and the numbers of increase and decrease are same basically, which are 42 and 43 respectively. Among the employees, the proportion of the fresh college students is relatively stable. But it is worth noting that there are 12 companies increasing the demand for college students considerably, it is about 4 companies more than before. It shows that the foreign trade environment isn't well, and some enterprises still can not increase the size of the introduction of college students. See Table1.

Table1. The trend in the enterprise's recruitment of foreign trade talents in recent years

\begin{tabular}{|c|c|c|c|c|}
\hline \multirow{2}{*}{$\begin{array}{c}\text { Trend } \\
\text { options }\end{array}$} & \multicolumn{2}{|c|}{ General situation } & \multicolumn{2}{c|}{$\begin{array}{c}\text { Fresh graduate's } \\
\text { situation }\end{array}$} \\
\cline { 2 - 5 } & $\begin{array}{c}\text { Number of } \\
\text { samples }\end{array}$ & Proportion & $\begin{array}{c}\text { Number of } \\
\text { samples }\end{array}$ & Proportion \\
\hline unchanged & 14 & $14 \%$ & 16 & $16 \%$ \\
\hline $\begin{array}{c}\text { increased } \\
\text { a little }\end{array}$ & 33 & $33 \%$ & 29 & $29 \%$ \\
\hline $\begin{array}{c}\text { increased } \\
\text { a lot }\end{array}$ & 9 & $9 \%$ & 12 & $12 \%$ \\
\hline $\begin{array}{c}\text { decreased } \\
\text { a little }\end{array}$ & 35 & $36 \%$ & 34 & $35 \%$ \\
\hline
\end{tabular}

Why enterprises are willing to hire fresh college students? What advantages do enterprises value most? The survey result shows (figure 3) that fresh college students are flexible, passionate, and hardworking, all of these characters are of great significance. Unlike our previous judgment, most enterprises don't consider the low cost as a starting point for hiring college students, and they also don't think that obeying the leadership arrangements is the advantage of college students. Additionally, some companies believe that fresh college students are promising, and companies can discover talents from them.

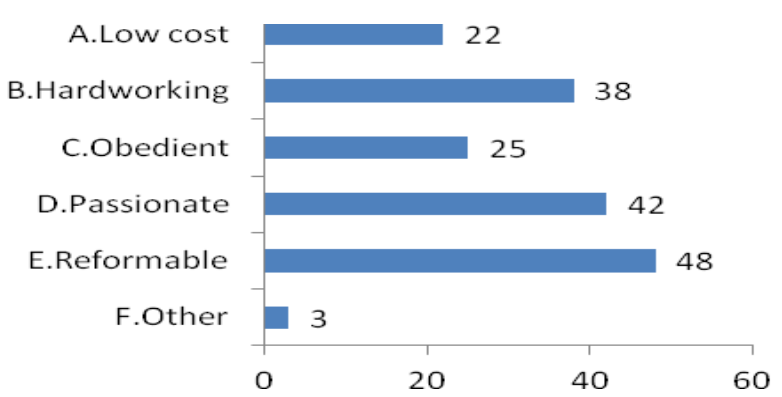

Figure 3. What advantages of fresh graduate enterprises value most

Recently, college student's low level of wages has been accompanied with the employment difficulty, which once aroused heated debate. So what level of wages are enterprises willing to give to fresh college students whose profession is international trade? Our survey result shows that the level of wages differs greatly among the enterprises, ranging from 1000 to $6000 \mathrm{RMB}$. The average level of wages is 3333 $\mathrm{RMB}$, the standard deviation is as high as 1040 . On the one hand, it shows that there exists am absolute gap of wage levels among the enterprises. On the other hand, it also indicates that enterprise's evaluations of personnel vary widely. Due to the large scale of college graduates, there is a great gap between the different schools and students, this may be the root cause of the high salary standard deviation.

\section{3 enterprise's evaluation on the personnel training in colleges}

What kind of person will be more likely to win in the fierce employment competitive? It is important to learn the factors which will be considered by enterprises. According to the survey (See figure 4), the most important factor is neither the college, nor the certificates and awards you get, but the internship experience. Secondly, the enterprise values foreign language ability a lot, especially if you master more languages, which also shows that foreign trade talents who graduate from language colleges are more popular in reality. Moreover, enterprises also value the international business communication skills and negotiation skills. In general, enterprises have already walked out of the stage of valuing the university background and certifications most, and went into a mature period where enterprises attach importance to practical and professional ability. 


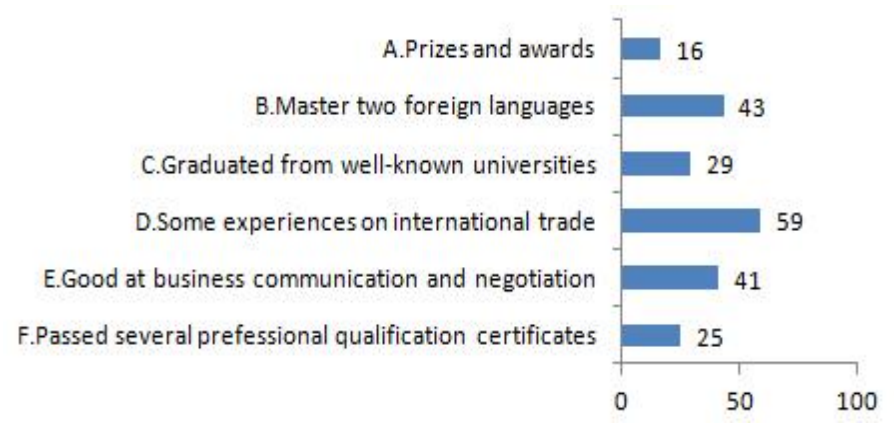

Figure 4. What factors enterprises will consider when choosing fresh graduates

In order to analyze what happened to the university education, it is necessary to know about the enterprise's negative evaluation on fresh college students after recruitment. According to the figure 5, the most prominent problem of college students is that their specialty foundation is not good, which indicates that there are some problems in the field of education. Secondly, their practical ability is poor, which is the reason why enterprises value internship experience a lot. The last problem is that college students isn't steadfast and have grandiose aims but puny abilities.

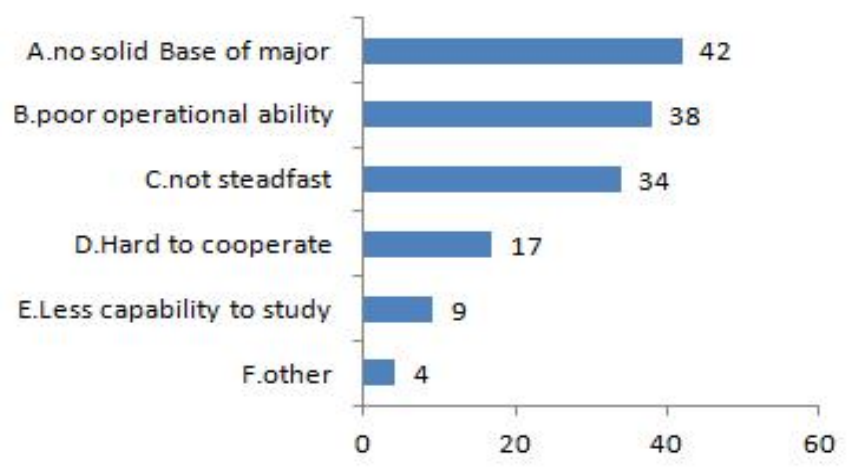

Figure 5.Problems of fresh graduates in enterprises' opinion

When it comes to the flaws of the university education, enterprise's answers are almost consistent, that is the disconnection with practice. The present education system cultivates students with poor manipulative ability, and it also takes much time for enterprises to train them, which will increase the enterprise's cost and risk. Some companies also think that the current universities neglect the moral education, causing student's inability to work with others and lack basic human norms such as being steadfast and honest.

Although enterprises generally accept the idea that college students should pay more attention to internship experience, it is very difficult for college students to seek internship units during summer vacation. Enterprises are unwilling to accept college students to do short-term internships, which sets up a problem for universities. Only by knowing about the idea of the enterprise and achieving mutual benefit can we solve the problem. According to the survey, among the reasons that enterprises accept the college students to do short-term internship, about 58 percent enterprises do it because of the human connection, only 15 percent of enterprises have a real demand for college students, and another 13 percent of enterprises are for public welfare. However, 19 percent of enterprises aim to seek talents they need through internship. That enterprises select talents by accepting interns is becoming more and more popular.

The main reason why enterprises are unwilling to accept interns is not that they don't need, but that the period of internship is too short. Enterprises can't attain any practical values with so short internship period. Of course, some enterprises just have no demand for interns at a certain stage, and some enterprises think it is too troublesome to manage the interns and fear that their commercial secret will be let out. In addition, they also worry that they may be responsible for the safety of interns (See figure 6).

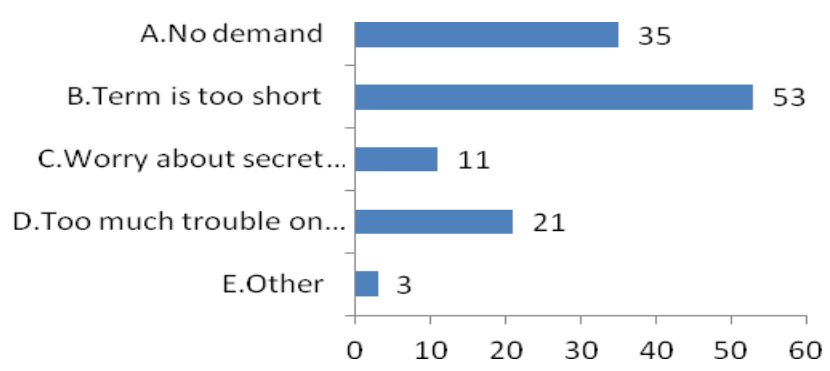

Figure 6. The reasons why enterprises are unwilling to accept college interns

For enterprises, they hope that universities can cultivate talents who are oriented to the social demand. The second is to help enterprises to carry out staff training. The third is to help enterprises solve business problems. Finally is to obtain the guidance of experts and professors (See figure 7). It is clearly that there is a realistic service requirement among enterprises. If universities can satisfy the enterprise's various needs, they can build a longterm cooperation between universities and enterprises, and obtain the further support from enterprises.

When it comes to the cooperation between universities and enterprises, that enterprises are willing to cooperate with universities to train talents makes us very surprised. In fact, universities hope to cooperate with enterprises to carry out investigation cooperation or practice base construction. It will be impossible to cooperate with enterprises if we just stand on our own benefits. With the aim of serving the economic development, universities should think deeply about the enterprise's demand for talents training, and this thought should be the foothold of the cooperation between universities and enterprises. 


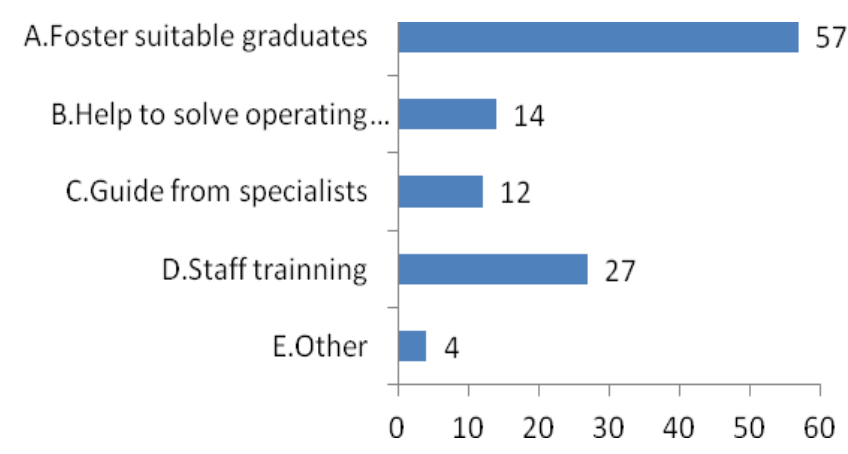

Figure 7. Things that enterprises hope colleges to do

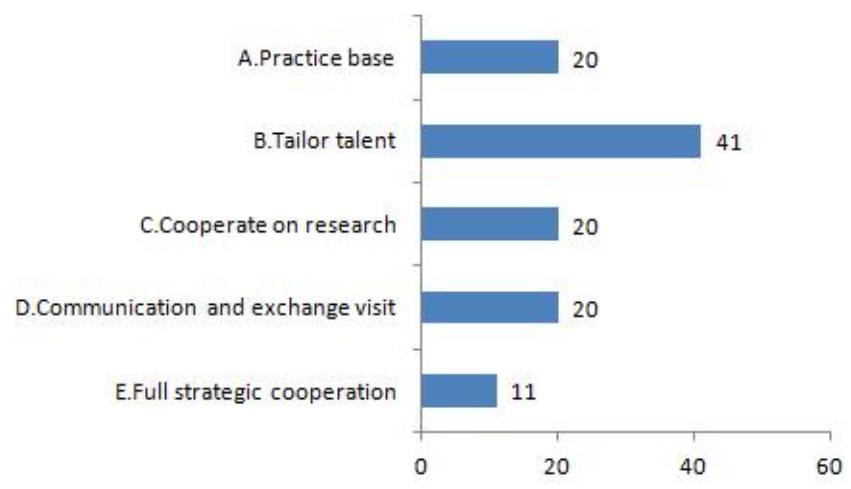

Figure 8 . Ways by which enterprise hope to cooperate with colleges

Finally, we investigated the senior manager's attitude in foreign trade enterprises towards the college education. When asked if they are willing to give a public welfare report or presentation, except for people who are not really good at it, there are 53 percent of people shows their willingness, and 17 percent of people are willing to participate in it frequently. It shows that the businessman isn't indifferent to education as imagined before. Instead, they are keen to participate in the college education, and willing to share their working experiences with college students voluntarily.

On the basis of questionnaire survey, we interviewed 13 Grade 2000's alumni who have been engaged in foreign trade work for a long time. We mainly talked about two questions: what is the most serious deficiency of college education in your opinion? What efforts do you think should be made to improve the quality of college education. Their answers are same exactly without any doubt. Firstly, they think college education needs practice, and colleges should strengthen professional practice and foreign language education. The result of the interview remains consistent with the result of questionnaire survey.

\section{CONCLUSIONS AND INSPIRATIONS}

In recent years, the environment of foreign trade in
Beijing has been deteriorating, enterprises are able to take active countermeasures, especially, more and more enterprises have paid more attention to product upgrading, promoting the quality of foreign trade in Beijing. The environment has a little influence on the enterprise's talent demand. Some enterprises still expand the size of the introduction of fresh college graduates. Fresh graduates are promising and passionate, which make them become the irreplaceable group in the employment market. However, today, higher education has entered a period of popularization, the gap of the college and student's individual quality led to a great difference of graduate's wages. The average wage level is 3333 RMB, which is far lower than the wage level of 5793 RMB in Beijing. When enterprises recruit fresh graduates, they pay more attention to the practical and professional ability. The background of the education and certificates are not as important as before. Fresh graduate's most prominent problem is the poor professional foundation, and the college education's most prominent defect is that it lags behind the practice. Enterprises hope to cooperate with colleges to train talents, and hope that colleges can cultivate talents who are oriented to social demand. Enterprises have realistic demand in colleges, and many businessmen are willing to support the educational career. However, in order to solve the problems that students have difficulty in finding an internship, it is necessary to establish a effective mechanism of university-enterprise cooperation. At the same time, it is also necessary to improve the management of professional internship and extend the period of internship.

The gap between the education and the practice is a major problem of colleges. It will be impossible to cultivate applied talents if teachers only pay attention to the theoretical research and don't practice. The education administrative sector should reform the educational system to encourage the cooperation with enterprises. Colleges should encourage teachers to practice, and take part in the enterprises' projects. Not only that, colleges also should bring in the expert resources of the industry, establish a exchange mechanism with enterprises, reform the system of courses, delete the outdated content, compress theoretical content, increase practice and internship and add advanced professional content. To solve the problem, changing our mind is a precondition. We should reform the inappropriate management system bravely.

\section{REFERENCES}

[1] Chunzi Gong and Liming Zhao,2014. Higher grade and employment: relationship study according to data. China Statistics (8):45-46. 